\title{
Procedural Rights as a CRUCIAL TOOL TO COMBAT Climate CHANGE
}

Svitlana Kravchenko*

\section{TABLE OF CONTENTS}

I. INTRODUCTION: WHY A PROCEDURAL HUMAN RIGHTS

Approach to Climate Change? . . . . . . . . . . . . . . . . 614

II. ACCESS TO INFORMATION . . . . . . . . . . . . . . . . 618

A. Human Rights Treaties . ..................... 618

B. Multilateral Environmental Agreements . ...........66 620

1. Active Duty to Disseminate Information .............6 622

2. Passive Duty to Give Information Upon Request ........66 625

C. Obtaining Climate Information from Private Companies . . . 629

D. Open and Transparent Systems of Reporting ........... 632

III. Public Participation In Decision-making Related to

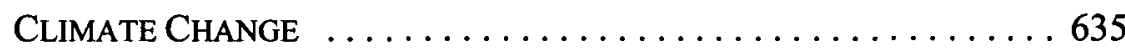

A. Legal Framework .........................6. 635

B. Public Participation in EIA ................. 638

C. Public Participation in Transboundary EIA ............ 641

D. The Role of Civil Society in Climate Change Negotiations: COP -15 ......................6 643

IV. Procedural Rights Language in the LCA Negotiation TEXT AND IN THE POST-COPENHAGEN TREATY ............6 644

V. Conclusion $\ldots \ldots \ldots \ldots \ldots \ldots \ldots \ldots \ldots \ldots \ldots \ldots \ldots \ldots \ldots$

* J.D., Lviv National University, Ukraine; Ph.D., All-Union Institute of Soviet Legislation, Moscow, U.S.S.R.; LL.D., National Law Academy, Ukraine; LL.M. Program Director, University of Oregon School of Law; Vice-Chair, UNECE Aarhus Convention Compliance Committee, Regional Governor of International Council of Environmental Law. 


\section{INTRODUCTION: WhY A PROCEDURAL HUMAN RIGHTS APPROACH TO Climate Change?}

We are witnessing runaway effects of climate change as evidenced by rapidly melting Arctic ice, increased intensity of storms and hurricanes, accelerating species extinctions, water shortage, droughts, and rising seas. ${ }^{1} \mathrm{Dr}$. James Hansen of the NASA Goddard Institute for Space Studies sees a planetary emergency very clearly and calls it a "global tipping point" that could be reached by $2016 .{ }^{2}$ Perhaps we can rescue ourselves from that planetary emergency if we come to see human-caused global climate change as violating fundamental human rights.

Just a few years ago a well recognized symbol of climate change was the polar bear. ${ }^{3}$ People concerned about global warming thought about how long polar bears would survive because of rapidly melting ice in the Arctic. Currently, climate change has evolved to have a more human face. We are concerned about the millions of humans displaced by disasters arising from more frequent extreme weather events such as hurricanes, cyclones, fires, and tornadoes. We are concerned about the possibility of 50 to 150 million climate refugees crossing borders looking for food and water. ${ }^{4}$ Climate change recently has been seen as having clear and immediate implications for the full enjoyment of human rights, not just as harmful to other species.

The human rights approach to international environmental law is becoming increasingly recognized in the human rights field. In September 2007, the

' According to the Fourth Report of the Intergovernmental Panel on Climate Change (IPCC), a rise of two degrees Celsius over pre-industrialized levels is inevitable as the atmospheric concentration of carbon dioxide approaches a destabilizing 450 parts per million. INTERGOVERNMENTAL PANEL ON CLIMATE CHANGE, ClimATE CHANGE 2007: SYNTHESIS REPORT 20-21 (2007), available at http://www.ipcc.ch/publications_and_data/ar4/syr/en/spms1.html.

${ }^{2}$ Earth's Climate Approaches Dangerous Tipping Point, ENV'T NEWSSERV., June 1, 2007, available at $\mathrm{http}: / / \mathrm{www}$.ecoearth.info/shared/reader/welcome.aspx?linkid=76684 .

${ }^{3}$ See Douglas Clark et al., Polar Bears, Climate Change, and Human Dignity: Disentangling Symbolic Politics and Seeking Integrative Conservation Policies, MERIDIAN, Fall/Winter 2008, at 1, available at $\mathrm{http}: / / \mathrm{www}$.polarcom.gc.ca/media.php?mid=3464 (discussing the plight of polar bears and their symbolic relevance to anthropogenic climate change).

${ }^{4}$ The UN University's Institute for Environment and Human Security (UNU-EHS) predicted that in 2010 there will be fifty million environmentally displaced people. Press Release, UNU-EHS, As Ranks of "Environmental Refugees" Swell Worldwide, Calls Grow for Better Definition, Recognition, Support (Oct. 11, 2005), http://www.ehs.unu.edu/file/get/3916. IPCC has suggested 150 million environmental refugees would exist by 2050 . Rajesh Chhabara, Climate Change Refugees Seek a New International Deal, Climate CHANGE CORP., Dec. 27, 2008, http://www.climatechangecorp.com/content.asp?contentid=5871. 
Maldives asked the UN Human Rights Council to consider the connection between climate change and the "full enjoyment of human rights." Two months later, the country hosted the Small Island States Conference on the Human Dimension of Global Climate Change. ${ }^{6}$

During the Conference, the world's Small Island States, which are among the most vulnerable communities on the planet to climate change, discussed the impact of global warming on individual people in their countries and also, for the first time, asked the question: how does climate change affect the human rights of our citizens. ${ }^{7}$

The Conference adopted the Male' Declaration on the Human Dimension of Global Climate Change. ${ }^{8}$ This international agreement explicitly states that "climate change has clear and immediate implications for the full enjoyment of human rights." 9

In March 2008 the Maldives and eighty co-sponsors secured the adoption of the UN Human Rights Council's Resolution 7/23 on "Human Rights and Climate Change." $" 10$ The resolution confirmed that global warming impacts the full enjoyment of human rights, and asked that the Office of the High Commissioner for Human Rights prepare a study on this impact." The resultant report on the relationship between climate change and human rights analyzed implications of the effects of climate change on the enjoyment of specific rights, vulnerabilities of specific groups, human rights implications of climate change-induced displacement and conflict, and the human rights implications of measures to address climate change. ${ }^{12}$

${ }^{5}$ Permanent Mission of the Republic of Maldives to the United Nations Office at Geneva, Human Rights and Climate Change, http://www.maldivesmission.ch/index.php?id=68 (last visited July 25,2010 ).

${ }^{6}$ Id.

${ }^{7} I d$.

${ }^{8}$ Id.

${ }^{9} I d$.

${ }^{10}$ Id.; H.R.C. Res. 7/23, U.N. Doc. A/HRC/7/23 (Mar. 28, 2008), available at http://ap. ohchr.org/documents/E/HRC/resolutions/A_HRC_RES_7_23.pdf.

"Id.

${ }^{12}$ Human Rights Council, Office of the U.N. High Commissioner for Human Rights [OHCHR], Report of the OHCHR on the Relationship Between Climate Change and Human Rights, U.N. Doc. A/HRC/10/61 (Jan. 15, 2009). 
Why should those two fields come together? When we talk about polar bears suffering and losing their habitat because of melting ice in the Arctic it is appealing largely to environmentalists who care about biodiversity. When we talk about people dying because of heat waves in Europe or because of droughts and shortage of water in Africa it touches the hearts and minds of the entire human population. When we put climate change in human rights language as violations of the rights to life, health, culture, water, and subsistence, we can apply the strong language of human rights treaties. We can use human rights institutions that are well established. Regional human rights courts, such as the European Court of Human Rights and Inter-American Court of Human Rights, have developed case law using and creatively interpreting fundamental human rights to stop degradation of the environment.

There is another reason as well to pursue a human rights approach to climate change, namely the limitations of the compliance mechanisms under existing international environmental law and the non-existence of a specifically focused international environmental court. The central institutions for multilateral environmental agreements (MEAs) are meetings of the parties whose primary task is to evaluate implementation and evolution of the treaty regime. Implementation or compliance committees created under MEAs usually consist of government representatives rather than independent experts and take a political rather than strictly legal approach to compliance. ${ }^{13}$ Compliance mechanisms under MEAs are soft and weak; they do not have "teeth." For example, the Kyoto Protocol Compliance Committee is in charge of enforcement of climate obligations and commitments of the parties to the Protocol. The methods of the Facilitative Branch consists of dialogue with the country involved as well as advice and facilitation. ${ }^{14}$ The Enforcement Branch has authority to "require a plan to be submitted by the Party concerned" and "shall endeavor to conduct the review and assessment of the plan ...." The language and consequences of non-compliance are vague. The strictest responses to a charge of non-compliance are deduction of excess emissions from the future emissions allowance and suspension of eligibility to participate

${ }^{13}$ Daniel Bodansky, Climate Change and Human Rights: Unpacking the Issues, 38 GA. J. INT'L \& COMP. L. 511, 515-16 (2010).

${ }_{14}$ U.N. Framework Convention on Climate Change [UNFCCC], Report of the Conference of the Parties Serving as the Meeting of the Parties to the Kyoto Protocol on its Second Session, Nairobi, Kenya, Nov. 6-17, 2006, Annex, Rules of Procedure of the Compliance Committee of the Kyoto Protocol, at 26, r.24, U.N. Doc. FCCC/KP/CMP/2006/10/Add.1 (Mar. 2, 2007).

${ }^{15}$ Id. at 26, r.25. 
in international emissions trading. ${ }^{16}$ Most of the MEAs' compliance mechanisms (with a few exceptions), and in particular the Kyoto Protocol Compliance Committee, accept submissions only from parties about their own non-compliance or against another party. The latter happens very rarely because parties want to keep good diplomatic relationships. ${ }^{17}$ Individual or non-governmental organizations' (NGOs) complaints generally are not allowed.

This Article will discuss how a subset of human rights-procedural rights-can play an important role in limiting climate change. These include freedom of expression and the right to seek and receive information, the right to participate in decision-making and the right of access to justice. States must address climate change through a transparent process of giving the public full and complete information during the early stages of decision-making in climate change related issues. States must also give the public a voice by allowing participation by all affected communities, including indigenous peoples.

In Part II, this Article will first discuss how freedom of expression and access to information are embedded in human rights treaties, multilateral environmental agreements, national constitutions and information laws, and in the jurisprudence of regional human rights and domestic courts, as well as national reporting and how these rights can be used for combating climate change. Part II will also briefly evaluate the right of investors to disclosure of climate risk information and the role of Securities and Exchange Commission (SEC) in light of the agency's new interpretive guidance on existing public company disclosure requirements relating to the issue of climate change.

In Part III, this Article will discuss public participation in decision-making related to climate change, first exploring the established legal framework for public participation in "soft law" MEAs, and in environmental impact assessments (EIAs), including the transboundary context. Part III concludes by providing case examples how procedural rights have been used to combat climate change.

Finally, Part IV will evaluate the role of civil society participation in the negotiation of an international treaty at the United Nations Framework

${ }^{16}$ U.N. Framework Convention on Climate Change [UNFCCC], Report of the Conference of the Parties Serving as the Meeting of the Parties to the Kyoto Protocol on its First Session, Montreal, Que., Nov. 28-Dec. 10, 2005, Annex, Procedures and Mechanisms Relating to Compliance Under the Kyoto Protocol, at 102, § XV, U.N. Doc. FCCC/KP/CMP/2005/8/Add.3 (Mar. 30, 2005).

${ }^{17}$ Svitlana Kravchenko, The Aarhus Convention and Innovations in Compliance with Multilateral Environmental Agreements, 18 COLO. J. INT'L ENVTL. L. \& POL'Y 1, 10-23 (2007). 
Convention on Climate Change (UNFCCC) Fifteenth Session of the Conference of the Parties (COP-15) in Copenhagen, Denmark, as well as the author's participation in the Working Group on Human Rights and Climate Change. This analysis aims to strengthen the language of the negotiation text by including procedural rights in preparation for a post-Copenhagen treaty.

\section{ACCESS TO INFORMATION}

Access to information would allow the public to be aware of governmental decisions that can impact climate change and have an impact on the enjoyment of their human rights. It would also allow the public to participate in criticizing, and possibly thereby improving, governmental climate-related decision-making on adaptation, mitigation, technology transfer, emission trading, monitoring, and reporting. This ultimately can help to prevent harmful activities that can cause significant damage to the right to life and the right to health.

\section{A. Human Rights Treaties}

Several human rights treaties address this fundamental human right to information.

The Universal Declaration of Human Rights (UDHR) was adopted in 1948 when climate change was not recognized to exist. One cannot find any reference to environmental rights or impacts of climate change on the enjoyment of human rights in that document or in other human rights treaties. However, the Universal Declaration of Human Rights proclaims, in Article 19, the right to freedom of opinion and expression. This right includes the "freedom ... to seek, receive, and impart information and ideas through any media and regardless of frontiers."18 As will be explained later in this Article, this right can be used in the climate change context.

The International Covenant on Civil and Political Rights (ICCPR) guarantees the right to freedom of opinion and expression at its Article 19, in a formulation similar to that of the UDHR. ${ }^{19}$ On a regional level, the European

${ }^{18}$ Universal Declaration of Human Rights, G.A. Res. 217A, at 71, art. 19, U.N. GAOR, 3d Sess., 1st plen. mtg., U.N. Doc. A/810 (Dec. 12, 1948).

${ }_{19}$ International Covenant on Civil and Political Rights art. 19(2), Dec. 16, 1966, 9 U.N.T.S. 171 ("Everyone shall have the right to freedom of expression; this right shall include freedom to seek, receive and impart information and ideas of all kinds, regardless of frontiers, either orally, in writing or in print, in the form of art, or through any other media of his choice."). 
Convention for the Protection of Human Rights and Fundamental Freedoms provides in Article 10: "Everyone has the right to freedom of expression. This right shall include freedom ... to receive and impart information and ideas without interference by public authority and regardless of frontiers." Article 13 of the American Convention on Human Rights contains a substantially similar provision. ${ }^{21}$

Finally, the African Charter of Human and Peoples' Rights states in Article 9:

1. Every individual shall have the right to receive information.

2. Every individual shall have the right to express and disseminate his opinions within the law. ${ }^{22}$

One possible interpretation of these provisions regarding the "right to receive" information is that a government may not block someone from receiving information from a willing provider, but that there is no specific duty on the part of government (public authorities) to be a provider of information. However, that narrow interpretation was rejected in 2006 by the InterAmerican Court of Human Rights under the American Convention on Human Rights in Claude Reyes et al. v. Chile. ${ }^{23}$ The court interpreted Article 13 of the American Convention as follows:

[B]y expressly stipulating the right to "seek" and "receive" "information," Article 13 of the Convention protects the right of all individuals to request access to State-held information, with the exceptions permitted by the restrictions established in the Convention. Consequently, this article protects the right of the individual to receive such information and the positive obligation of the State to provide it, so that the individual may have access

${ }^{20}$ European Convention for the Protection of Human Rights and Fundamental Freedoms art. 10(1), Nov. 4, 1950, 213 U.N.T.S. 221.

${ }^{21}$ American Convention on Human Rights art. 13(1), Nov. 22, 1969, 1144 U.N.T.S. 123 ("Everyone has the right to freedom of thought and expression. This right includes freedom to seek, receive, and impart information and ideas of all kinds, regardless of frontiers, either orally, in writing, in print, in the form of art, or through any other medium of one's choice.").

${ }^{22}$ African Charter on Human and Peoples' Rights, June 27, 1981, 1520 U.N.T.S. 217.

${ }^{23}$ Claude Reyes et al. v. Chile, Case 12.108, Inter-Am. C.H.R. (ser. C) Rep. No. 151, $\mid 77$ (Sept. 19,2006), available at http://www.oas.org/DIL/access_to_information_human_right_Ca se_of_Claude_Reyes_et_al_vs_Chile.pdf. 
to such information or receive an answer.... The information should be provided without the need to prove direct interest or personal involvement in order to obtain it, except in cases in which a legitimate restriction is applied. ${ }^{24}$

In several countries, including Korea, India, Japan, Pakistan, Israel, and France, the constitutional right of freedom of expression has similarly been interpreted by courts to encompass a right of access to information. ${ }^{25}$

This broad interpretation of the freedom of expression includes access to information as a fundamental human right and as an obligation of the government to provide information to the public about climate change (science, existing treaties and country commitments, domestic laws and regulations, national adaptation and mitigation plans, information about emission trading and how money is spent, carbon sinks, technology transfer, etc.). ${ }^{26}$ This information can be used by the public to combat climate change.

\section{B. Multilateral Environmental Agreements}

A number of multilateral environmental agreements(MEAs) also guarantee the right to information.

Principle 10 of the Rio Declaration first laid the groundwork for international environmental agreements on access to information. ${ }^{27}$ In Europe, the Caucasus, and Central Asia, the Aarhus Convention on Access to Information, Public Participation in Decision-Making and Access to Justice in Environmental Matters (the Aarhus Convention) was developed, signed in 1998, and now ratified by forty-four parties. ${ }^{28}$ According to former United Nations Secretary-General Kofi Annan, the Aarhus Convention is

${ }^{24} \mathrm{Id}$.

25 DAVID BANISAR, PRIVACY INT'L, FREEDOM OF INFORMATION AROUND THE WORLD 2006, at 17 (2006), available at http://www.privacyinternational.org/foi/foisurvey2006.pdf.

${ }^{26}$ Svitlana Kravchenko, Is Access to Environmental Information a Fundamental Human Right?, 11 OR. REV. INT'L L. 227, 229-42 (2009).

${ }_{27}$ U.N. Conference on Environment and Development, Rio de Janeiro, Braz., June 3-14, 1992, Rio Declaration on Environment and Development, princ. 10, U.N. Doc. A/CONF.151/26 (vol. I) (Aug. 12, 1992) [hereinafter Rio Declaration].

${ }^{28}$ Convention on Access to Information, Public Participation in Decision-Making and Access to Justice in Environmental Matters, June 25, 1998, 2161 U.N.T.S. 447 [hereinafter Aarhus Convention], available at http://www.unece.org/env/pp/documents/cep43e.pdf. 
the most impressive elaboration of principle 10 of the Rio Declaration, which stresses the need for citizens' participation in environmental issues and for access to information on the environment held by public authorities. As such it is the most ambitious venture in the area of "environmental democracy" so far undertaken under the auspices of the United Nations. ${ }^{29}$

Secretary-General Annan also noted that, "[a]lthough regional in scope, the significance of the Aarhus Convention is global."

Other MEAs have included obligations of parties to make information held by government accessible to members of the public. For example, Article 15(2) of the Rotterdam Convention on the Prior Informed Consent Procedure for Certain Hazardous Chemicals and Pesticides in International Trade requires state parties to ensure, "to the extent practicable" that the public has appropriate access to certain information on chemical handling, accident management, and alternatives. ${ }^{31}$ Article 10(1) of the Convention on Persistent Organic Pollutants requires each party to ensure that the public has access to public information. ${ }^{32}$ Article 9 of the Convention on the Transboundary Effects of Industrial Accidents requires parties to "ensure that adequate information is given to the public in the areas capable of being affected by an industrial accident arising out of a hazardous activity." 33

Most importantly, Article 6 of the 1992 United Nations Framework Convention on Climate Change (UNFCCC) requires state parties to " $[\mathrm{p}]$ romote

${ }^{29}$ U.N. ECON. COMM. FOR EUR. [UNECE], THE AARHUS CONVENTION: AN IMPLEMENTATION GUIDE, at v., U.N. Doc. ECE/CEP/72, U.N. Sales No. E.00.II.E.3 (2000), available at http://www. unece.org/env/pp/acig.pdf.

${ }^{30} \mathrm{Id}$.

${ }^{31}$ Convention on the Prior Informed Consent Procedure for Certain Hazardous Chemicals and Pesticides in International Trade art. 15(2), Sept. 10, 1998, S. TREATY Doc. No. 106-21, 2244 U.N.T.S. 337; U.N. ENV'T PROGRAMME [UNEP], SECRETARIAT OF THE ROTTERDAM CONVENTION, ROTTERDAM CONVENTION ON THE PRIOR INFORMED CONSENT PROCEDURE FOR Certan hazardous Chemicals and Pesticides In INTERnational Trade: TeXt and ANNEXES 14 (2005), available at http://www.pic.int/en/ConventionText/ONU-GB.pdf.

${ }^{32}$ Stockholm Convention on Persistent Organic Pollutants, May 22, 2001, S. TREATY Doc. No. 107-5, 2256 U.N.T.S. 119, available at http://chm.pops.int/Portals/0/Repository/conf/ UNEP-POPS-CONF-4-AppendixII.5206ab9e-ca67-42a7-afee-9d90720553c8.pdf.

${ }^{33}$ Convention on the Transboundary Effects of Industrial Accidents art. 9, Mar. 17, 1992, 2105 U.N.T.S. 457. 
and facilitate at the national and, as appropriate, subregional and regional levels ... public access to information on climate change and its effects ...."34

What kind of information should be available so that citizens can use it to combat climate change? Should such information include climate change science, policies and measures, planned and existing activities related to adaptation and mitigation, and enhancement of energy efficiency in relevant sectors of the national economy? Should it also include international treaties, conventions, and agreements, as well as information about their implementation in the form of national communications?

How does the right to information as expressed in MEAs (and in particular in Article 6 of the UNFCCC) help to combat climate change? We will look at the active duty to disseminate information and the passive duty to give information upon request (Article 4 of the UNFCCC). We will first look at access to information as an active duty of the government and how it can be used for climate change purposes.

\section{Active Duty to Disseminate Information}

Several MEAs require active dissemination of information. Parties to the Aarhus Convention have a duty to disseminate information on climate change according to the Article 5, and according to Article 6 of the UNFCCC to "promote and facilitate... public access to information on climate change and its effects." 35

Article 5 of the Aarhus Convention requires the following:

2. Each Party shall ensure that, within the framework of national legislation, the way in which public authorities make environmental information available to the public is transparent and that environmental information is effectively accessible ... by: ...

(c) Providing access to the environmental information contained in lists, registers or files ... free of charge ....

3. Each Party shall ensure that environmental information progressively becomes available in electronic databases which

\footnotetext{
${ }^{34}$ United Nations Framework Convention on Climate Change art. 6(a), 6(a)(ii), opened for signature, May 9, 1992, S. TREATY DOC. No. 102-38, 1771 U.N.T.S. 107 [hereinafter UNFCCC].

${ }^{35}$ Id. art. 6.
} 
are easily accessible to the public through public telecommunications networks. ${ }^{36}$

Article 12 of the UNFCCC requires parties to include in national communications various kinds of information including the following:

1. (a) A national inventory of anthropogenic emissions by sources and removals by sinks of all greenhouse gases .... (b) A general description of steps taken or envisaged by the Party to implement the Convention ....

2. Each developed country Party and each other Party included in Annex $I$ shall incorporate in its communication the following elements of information:

(a) A detailed description of the policies and measures that it was adopted to implement its commitment under Article $4 \ldots$; and

(b) A specific estimate of the effects that the policies and measures referred to in subparagraph (a) immediately above will have on anthropogenic emissions by its sources and removals by its sinks of greenhouse gases .... ${ }^{37}$

The public also has the right to know whether the numbers of a government's commitments in negotiations are real. For example, the NGO coalition called Climate of the Future Without Dander for Life in Ukraine discovered, before UNFCCC COP-14 in Poznan, that Ukraine's commitment to reduce $\mathrm{GHG}$ emissions $20 \%$ by 2020 in reality meant an emissions increase by $70 \%$ due to economic decline after the collapse of the Soviet Union. ${ }^{38}$ The coalition tried to push the government to change its position and to tell the truth to the international community also before COP-15 in Copenhagen. When the NGO coalition failed to convince Ukraine's government, it made a statement at COP-15 revealing the real situation. ${ }^{39}$

${ }^{36}$ Aarhus Convention, supra note 28 , art. 5.

${ }^{37}$ UNFCCC, supra note 34, art. 12.

38 UKrainian NGO Working Group on Climate Change, CrITICAL OVERVIEW OF THE Postrion of Ukraine on Climate Change Mitigation for Post-2012 Negotiations (providing a critical overview of the position of Ukraine on climate change mitigation for post2012 negotiations) (on file with author).

${ }^{39}$ Climate Action Network International gave Ukraine the "Fossil of the Day" award on December 8, 2009, during international negotiations in Copenhagen. The award is given to the 
According to Article 7 of the Kyoto Protocol, "Each Party included in Annex I shall incorporate in its national communication, submitted under Article 12 of the Convention, the supplementary information necessary to demonstrate compliance with its commitments under this Protocol ...."40 The public also has the right to be informed about issues relating to climate change that include: emission trading and activities related to other flexibility mechanisms under the Kyoto Protocol; investment in green technology projects; financing of such projects; technology transfer; protecting carbon sinks and reservoirs of greenhouse gases; and other important matters.

For example, the Bolivian government used the right of the public to access information and its own duty to disseminate information on Reduction of Deforestation and Forest Degradation (REDD) ${ }^{41}$ The Access Initiative $(\mathrm{TAI})^{42}$ coalition in Bolivia has been working with the Vice Minister of the Environment, Biodiversity, and Climate Change on improving the public's access to information. ${ }^{43}$ TAI "observed the lack of information on climate negotiations and that stakeholders are not participating in the design of climate policies." ${ }^{\text {"44 }}$ So, the Vice Minister together with TAI organized a "[s]eminar to discuss REDD jointly with the National Program on Climate Change."45 Specifically, "[t]he seminar objective was to disseminate the existing information on REDD, and to advance towards a participatory elaboration of a REDD strategy." 46

Article 6 of UNFCCC also requires parties to "promote and facilitate ... (i) the development and implementation of educational and public awareness programmes on climate change and its effects ...."47 Interesting in this regard is the case Dimmock $v$. Secretary of State for Education and Skills. ${ }^{48}$

parties who played the worst role in the negotiations at COP-15. Fossil Awards Day 2: World's Shame Rains on Ukraine, http://www.fossiloftheday.com/?p=126 (last visited June 19, 2010).

${ }^{40}$ Kyoto Protocol to the United Nations Framework Convention on Climate Change art. 7(2), Dec. 11, 1997, 37 I.L.M. 22 (1998) [hereinafter Kyoto Protocol].

${ }^{41}$ Access to Information on Climate Change and Forests in Bolivia, http://www.accessiniti ative.org/blog/2009/09/access-information-climate-change-and-forests-bolivia (Sept. 2, 2009).

${ }^{42}$ The Access Initiative (TAI) is a global network that promotes access to information, participation, and justice in environmental decision-making. About the Access Initiative, http:// www.accessinitiative.org/about (last visited June 19, 2010).

${ }^{43}$ Access to Information on Climate Change and Forests in Bolivia, supra note 41.

${ }^{44} I d$.

${ }^{45} \mathrm{Id}$.

$48 \mathrm{Id}$.

${ }^{47}$ UNFCCC, supra note 34, art. 6(a).

${ }^{48}$ [2007] EWCA (Admin.) 2288 (Eng.). 
According to the Columbia Law School Center for Climate Change Law, "[a] United Kingdom Court upheld [the] Secretary of State's decision to distribute Al Gore's documentary, 'An Inconvenient Truth' to English state schools as a teaching aid."49 The plaintiff parent claimed the government's decision to distribute the film on global warming violated of the Education Act of 1996 because it amounted to the promotion of "partisan political views." "The court found the film substantially founded upon scientific evidence and determined that it could be shown, as long as teachers provided guidance explaining that, (1) some matters contained in the film were not supported or promoted by the government, and (2) the errors contained in the film." 51

\section{Passive Duty to Give Information Upon Request}

Public authorities have an obligation to give information upon request. This includes environmental and climate change-related information. In many regions of the world, a right of wide access to information exists. ${ }^{52}$ All information should be accessible unless a provision of law specifically exempts it from disclosure. The principle is reflected in the Aarhus Convention, which states a general rule in Article 4 that each party to the Convention "shall ensure that, subject to the following paragraphs of this article, public authorities, in response to a request for environmental information, make such information available to the public ...."53

The African Commission on Human and Peoples' Rights has interpreted in the language in Article 9 of the African Charter on Human and Peoples' Rights that "the right to receive information" means that "everyone has a right to access ... information [held by public bodies], subject only to clearly defined rules established by law." $\$ 4$

On the national level, in the U.S., the Freedom of Information Act (FOIA) provides in Section 552(a)(3)(A) that "each agency ... shall make [documents

${ }^{49}$ Colum. L. Sch. Ctr. For Climate Change L. Non U.S. Climate Change Litigation CHART 69 (2009), http://www.law.columbia.edu/centers/climatechange/resources/LitChartNon US (follow hyperlink for chart).

${ }^{50}$ Id.

${ }^{51}$ Id.

52 For more detail see Kravchenko, supra note 26, at 237-41.

53 Aarhus Convention, supra note 28, art. 4(1) (emphasis added).

54 Declaration of Principles on Freedom of Expression in Africa art. IV(1), Afr. Comm'n on Hum. and Peoples' Rights, 32d Sess. (Oct. 23, 2002), available at http://www.achpr.org/engl ish/declarations/declaration_freedom_exp_en.html. 
and other records] promptly available to any person," subject only to carefully limited exemptions listed in Section 552(b). ${ }^{55}$ In December 2007 the U.S. Congress passed the Openness Promotes Effectiveness in our National Government Act (OPEN Government Act of 2007), ${ }^{56}$ amending FOIA in various ways. The new 2007 legislation further asserted that the American people possess a "fundamental 'right to know." 57 Moreover, U.S. President Barack Obama stated in the Memorandum to the Heads of Executive Departments and Agencies:

The Freedom of Information Act should be administered with a clear presumption: In the face of doubt, openness prevails .... All agencies should adopt a presumption in favor of disclosure, in order to renew their commitment to the principles embodied in FOIA, and to usher in a new era of open Government. The presumption of disclosure should be applied to all decisions involving FOIA. ${ }^{58}$

In 2006, Citizens for Responsibility and Ethics in Washington (CREW) requested from the Council on Environmental Quality (CEQ) records relating to the causes of climate change, invoking FOIA; CEQ provided many documents, but CREW sought a court order under FOIA requiring CEQ to release all relevant records. ${ }^{59}$ By May 2007, CEQ had provided 16,000 pages of documents to CREW and was about halfway through the remaining 27,000 pages. ${ }^{60}$

Alongside this lawsuit were allegations that political appointees at CEQ edited agency reports in order to minimize the appearance of both "danger and the human causes of climate change." ${ }^{\prime 61}$ In July, 2006, the House Committee on Government Reform requested from CEQ any documents and communications relating to the agency's alleged edits of climate change

555 U.S.C. $\$ 552$ (2006).

${ }^{56}$ Pub. L. No. 110-175, 121 Stat. 2524 (2007).

${ }^{57}$ Id. $\S 2(6)$

${ }^{38}$ Memorandum for the Heads of Executive Departments and Agencies on the Freedom of Information Act, 74 Fed. Reg. 4681 (Jan. 26, 2009).

s9 Robert Meltz, Cong. Res. Ser., No. RL32764, Climate Change Litigation: A GROWING PHENOMENON 23 (2007).

${ }^{60}$ Id.

${ }^{61}$ Id. 
reports, any efforts to influence government scientists, and climate changerelated communications with federal agencies and non-governmental parties. ${ }^{62}$

In Ukraine, as a result of the public outcry about the secrecy surrounding the explosion at the Chernobyl nuclear plant, the government subsequently adopted, as one of the first laws of independent Ukraine, the Law on Information. ${ }^{63}$ It provides a "guaranteed right to information; transparency, accessibility, and freedom of information exchange; unbiased and authentic information; complete and accurate information ...." ${ }^{64}$ Legislative, executive, and judicial authorities, as well as governmental officials, are obliged to provide information. Furthermore, the Constitution of Ukraine in Article 50 declares wide access to information: "Everyone is guaranteed the right of free access to information about the environmental situation ... . No one shall make such information secret." 65

Despite such legal requirements, the old habit of secrecy is hard to change. The Ukrainian non-governmental organization Environment-People-Law (EPL) requested that the Ministry of the Environment provide information on climate change policy (including, inter alia, mitigation measures, obligations on public information, and development and implementation of educational and public awareness programs on climate change and its effects). ${ }^{66}$ The request was ignored by the Ministry. ${ }^{67} \mathrm{EPL}$ alleged that the Ministry did not fulfill the requirements of the UNFCCC regarding informing the public on climate change issues. ${ }^{68}$ EPL filed a suit challenging the denial of information and also challenging the inaction of the Ministry concerning its obligation to disseminate information on its climate change activities. ${ }^{69}$ EPL asked the court to oblige the Ministry to take certain actions and impose a penalty on the

${ }^{62}$ Law of Ukraine on Information, 1992, No. 2567-XII, available at http://zakon.rada.gov. ua/cgi-bin/laws/main.cgi?nreg=2657-12.

${ }_{63} I d$.

${ }^{64}$ Id.

${ }^{65}$ UKR. CONST. art. 50, available at http://www.rada.gov.ua/const/conengl.htm.

${ }^{66}$ Environment People Law, Violation of the Legislation on the Right to Information and Public Participation in Climate Change Issues by the Ministry of Environmental Protection in Ukraine, http://epl.org.ua/en/lawnbspnbspnbsp/access-to-information/cases/violation-of-the-legis lation-on-the-right-to-information-and-public-participation-in-climate-change-issues-by-the-min istry-of-environmental-protection-in-ukraine/ (last visited June 19, 2010).

${ }^{67} \mathrm{Id}$.

${ }^{68} \mathrm{Id}$.

${ }^{69}$ See id. (confirming that the Commercial Court of the Lviv Region opened the proceeding from a lower court ruling dated May 16, 2008). 
officials responsible for the violation of the legislation. ${ }^{70}$ As of the time of this writing, the case is pending.

The same organization, EPL, is also using legal procedures to discover whether Ukraine is using the Kyoto Protocol to solve climate change problems or, perhaps, just to make some easy money. Ukraine and Japan "have agreed on cooperation in the area of elaborat[ion] of new energy and industrial technologies and [the] introduc[tion] of green investments." "71 A cooperation agreement was signed on March 18,2009, by the head of the National Agency for Ecological Investments of Ukraine and the chairman of Japan's New Energy and Industrial Technology Development Organization. ${ }^{72}$ Under the signed agreement, Ukraine, "in compliance with [the] Kyoto Protocol," will give to Japan thirty million units of emission quotas for greenhouse gas emissions. ${ }^{73}$ Prime Minister of Ukraine, Yulia Tymoshenko, asserted that the financial resources received as a result of signing the document would facilitate cooperation in the introduction of advanced technologies and "will enable improvement of [the] environment and [the] forming of a new ecological and energy saving policy." ${ }^{4}$ The agreement is supposed to be beneficial for both sides: "Japan's greenhouse gas emissions rose to a record 1.37 billion tons, putting it at risk of failing its Kyoto target to cut emissions by 6 percent from the 1990 level of 1.26 billion tons ...."75 Japan pledged "to buy 100 million tons in carbon offsets from abroad during the 2008-2012 Kyoto period to supplement the country's voluntary industry-led plans to improve energy efficiency and reduce fossil fuel use."76 Ukraine seeks to deliver thirty million tons of Assigned Amount Units (AAUs) to Japan and

${ }^{70}$ EPL argued that, according to Article 4, paragraph 3(d) of the Aarhus Convention, information on emissions that is relevant for the protection of the environment shall be disclosed. Id. As discussed above, the Constitution of Ukraine declares wide access to information. See supra note 65 and accompanying text. Furthermore, bilateral international agreements cannot be confidential according to the Law of Ukraine "On international treaties of Ukraine." Id.

${ }^{71}$ Press Release, Cabinet of Ministers of Ukraine Secretariat, Ukraine and Japan to Devise New Energy and Industrial Technologies and Introduce Green Aid (Mar. 18, 2009), http://www. $\mathrm{kmu}$.gov.ua/control/en/publish/article?art_id=2012831 15\&cat_id=2297108.

${ }^{72} I d$.

${ }^{73} \mathrm{Id}$.

${ }^{74}$ Press Release, Embassy of Ukraine in Japan, Kyoto Protocol Based Agreements Signed, http://www.mfa.gov.ua/japan/en/news/detail/21741.htm (last visited June 19, 2010).

75 Japan to Seal Carbon Deal with Ukraine Soon, KYIV Post (Ukr.), Mar. 18, 2009, http:// www.kyivpost.com/business/bus_general/37752.

${ }^{76} \mathrm{Id}$. 
implement six specific environmental measures in Ukraine, including renewable energy projects. ${ }^{77}$ The value of the deal was not disclosed. ${ }^{78}$

GHG emission trading must be executed with transparency and public access to information on such activities. ${ }^{79}$ "Money received from GHG emissions trading must be spent on environmental projects according to" established transparent procedure. ${ }^{80}$ EPL maintains that the public has the right to know what amount of money Ukraine received for selling AAU credits to Japan and how the money is going to be spent. ${ }^{81}$ EPL sent a request to the National Agency for Ecological Investments (NAEI) asking make clear the legal nature of this agreement and the amount of money; who will control implementation of the agreement; which projects will be chosen for financing; and the procedure for allocation of the revenues. ${ }^{82}$ The response indicated that the information was confidential. EPL filed a case on the denial of access to information. ${ }^{83}$ The Lviv circuit administrative court opened a case against the Cabinet of Ministers of Ukraine and the NAEI ${ }^{84}$ EPL brought suit under national laws, the UNFCCC, and the Kyoto Protocol ${ }^{85}$ As of the time of this writing, the case is pending.

Meanwhile, Victor Yanukovych, the newly elected President of Ukraine, announced that the $\$ 375$ million that the country received by selling its greenhouse gas emission quotas under the Kyota Protocol "had been 'plundered." "86 Public concerns appear to have been well-grounded.

\section{Obtaining Climate Information from Private Companies}

A variety of methods may be used to achieve access to information and can be used to combat climate change when climate science information is

77 Risa Maeda, Japan Buys 30 Mln. Tonnes of CO2 Rights from Ukraine, REUTERS, Mar. 18, 2009, http://uk.reuters.com/article/oilRpt/idUKT1231820090318.

${ }^{78}$ Id.

${ }^{79}$ Environment People Law, Access to Information on International GHG Emissions Trading by Ukraine, http://epl.org.ua/en/environment/climate-change/cases/lawsuit-on-climate-changeinitiated-by-epl/\#c74 (last visited June 19, 2010).

${ }^{80}$ Id.

${ }^{81} I d$.

${ }^{82} I d$.

${ }^{83}$ Id.

${ }^{84} \mathrm{Id}$.

${ }^{85}$ Id.

${ }^{86}$ Ukraine 's Profits from Unspent Kyoto Quotas "Plundered"- Yanukovych, RIA NovOSTI (Ukr.), Apr. 23, 2010, http://en.rian.ru/exsoviet/20100423/158708808.html. 
withheld as confidential. Kivalina, an Inupiat Eskimo village of 400 perched on a barrier island north of the Arctic Circle, has accused two dozen fuel and utility companies of contributing to cause climate change and as a result accelerating the island's erosion. ${ }^{87}$ The village wants the companies, including ExxonMobil, Shell Oil, and many others producing GHG emissions, to pay the costs of relocating to the mainland, which could amount to as much as $\$ 400$ million. ${ }^{88}$ One of the legal theories in this case is conspiracy ${ }^{89}$ The plaintiffs allege that the companies had scientific information regarding how their activities impact the climate fifteen years ago, but they kept information confidential and intentionally misled the public. ${ }^{90}$ If the case ultimately survives the defendants' motion to dismiss, the plaintiffs' lawyers will likely embark wide-ranging civil discovery, the same type that forced tobacco companies to reveal sensitive internal documents.

Another method involves forcing companies to make disclosures to investors. In November 2009, investors representing about $\$ 1$ trillion in assets filed a supplement to a 2007 petition, requesting updated information about the risks of climate change. The petition also asked that the U.S. Securities and Exchange Commission (SEC) require that all companies include reports of climate-related risks when reporting other financial risks. ${ }^{91}$

The world's largest investors convened at the Investor Summit on Climate Risk, at UN Headquarters in New York City, on January 14, 2010.92 The theme was "Climate Risk: Developing a Low-Carbon Economy, Leveraging Private Investment." 93 This high-level forum for investors met to discuss the implications of the negotiations held during COP-15 in Copenhagen. ${ }^{94}$ "The Summit explored how the rapid global shift to clean technologies and energy efficiency can stimulate economic growth, and highlighted how investors can participate in the low-carbon transition." 95

${ }^{87}$ Native Vill. of Kivalina v. ExxonMobil Corp., 663 F. Supp. 2d 863, 868 (N.D. Cal. 2009).

${ }^{88}$ Id. at 868-69.

${ }^{89}$ Id. at 869 .

${ }^{90}$ Complaint for Damages If 5, Native Vill. of Kivalina v. ExxonMobil Corp., 663 F. Supp. 2d 863 (N.D. Cal. 2009) (No. CV 08-1138 SBA), available at 2008 WL 594713.

${ }_{91}$ Leora Falk, Investors Push for Disclosure of Risk; Climate Change May See SEC Action Soon, WORLDCLIMATECHANGE REPORT, Nov. 24, 2009, http://climate.bna.com/Home.html (enter "Investors Push for Disclosure" in search box, scroll down to find article) (subscription required).

${ }_{92}$ Press Release, Int'l Inst. for Sustainable Dev., Investors Call for Strong National Climate Policies (Jan. 14, 2010), http://www.iisd.org/calendar/event.aspx?id=7089.

${ }^{93} \mathrm{Id}$.

94 Id.

${ }^{95}$ Id. (emphasis added). Furthermore, participating investors "released a statement on 
Climate risks can include physical risks from changing weather patterns or sea level rise, regulatory risk for companies that are likely to be required to reduce their emissions under greenhouse gas regulations, or risks related to marketing as consumers increasingly seek out environmentally conscious companies.

On January 27, 2010 the SEC voted to provide public companies with interpretive guidance on existing disclosure requirements as they apply to business or legal developments relating to the issue of climate change. ${ }^{96}$ Federal securities laws and SEC regulations require certain disclosures by public companies for the benefit of investors. Occasionally, to assist those who provide such disclosures, the SEC provides guidance on how to interpret the disclosure rules on topics of interest to the business and investment communities. The SEC's interpretive releases do not create new legal requirements nor modify existing ones, but are intended to provide clarity and enhance consistency for public companies and their investors. In this case,

[t]he interpretive guidance highlights four areas where climate change is most likely to affect businesses in ways that could affect shareholder and investment decisions. Those four areas are the effects of existing or pending legislation and regulations that address greenhouse gas emissions, the effects of international accords and treaties on climate change, physical risk caused by changing weather patterns, and indirect consequences of regulation and business trends.

Physical impacts could include risks to locations more prone to flooding or operations heavily dependent on water that may face a water shortage. Indirect consequences include decisions

\footnotetext{
'Catalyzing Investment in a Low-Carbon Economy,' calling on the US and other governments to move quickly to adopt strong national climate policies that will spur low-carbon investments to reduce emissions causing climate change." Stating " "we cannot wait for a global treaty," " U.S., European, and Australian groups that represent $\$ 13$ trillion in assets "called on the US Congress and other global decision-makers 'to take rapid action' on carbon emission limits, energy efficiency, renewable energy, financing mechanisms and other policies that will accelerate clean energy investment and job creation." Investor groups also underscored the "competitive advantages for countries with comprehensive climate and energy policies." Id.

${ }^{96}$ Leora Falk, SEC Approves Guidance for Companies to Disclose Climate Change-Related Risks (Updated), WORLD CLIMATE CHANGE REPORT, Jan. 27, 2010, http://climate.bna.com/ Home.html (enter "SEC Approves Guidance" in search box, scroll down to find article) (subscription required).
} 
by consumers to purchase a competitor's product that is less emissions-intensive. ${ }^{97}$

For instance, a company may face decreased demand for goods that produce significant greenhouse gas emissions or increased demand for goods that result in lower emissions than competing products. A company should consider, for disclosure purposes, the actual or potential indirect consequences it may face due to climate change-related regulatory or business trends. Companies should also evaluate for disclosure purposes the actual and potential material impacts of environmental matters on their business. ${ }^{98}$ Indirect consequences can include decisions by consumers to purchase a competitor's product that is less emissions-intensive. ${ }^{99}$ "[A] new law or international treaty limiting greenhouse gas emissions is likely to require new investments or increase operating costs" and should be disclosed. ${ }^{100}$ Moreover, "A climate change law could also help companies that produce renewable fuels or environmentally friendly technologies, like wind turbines. That, too, should trigger disclosure."101

\section{Open and Transparent Systems of Reporting}

The right of access to information should also be considered in connection with commitments in international agreements. This was a very contentious issue at COP-15. Developed countries, the U.S. delegation in particular, wanted countries to include strong provisions on monitoring, verification, and reporting of actions in any climate change agreement, including on-site monitoring and inspections as a condition of giving financial support and transfer of technology. Developing countries, particularly China, argued that this would be an intrusion on their state sovereignty. ${ }^{102}$

${ }^{97}$ Id.

${ }_{98}$ Press Release, U.S. Sec. and Exch. Comm'n, SEC Issues Guidance on Disclosure Related to Business or Legal Developments Regarding Climate Change (Jan. 27, 2010), http://www.sec. gov/news/press/2010/2010-15.htm.

${ }_{99}$ Falk, supra note 96.

${ }^{100}$ Editorial, Climate Change and the S.E.C., N.Y. TMMES, Jan. 31, 2010, at WK9, available at http://www.nytimes.com/2010/01/31/opinion/31 sun3.html.

${ }^{101}$ Id.

${ }^{102}$ See Jim Tankersley, U.S., China Concessions Give Climate Talks Big Boost, L.A. TIMES, Dec. 18, 2009, http://articles.latimes.com/2009/dec/18/world/la-fg-climate-talks18-2009dec 18 (discussing China's hesitation to accede to transparency promises because of state sovereignty concerns). 
One of the important decisions of the COP- 15 is found in paragraph 4 of the Copenhagen Accord, stating in relevant part: "Delivery of reductions and financing by developed countries will be measured, reported and verified in accordance with existing and any further guidelines adopted by the Conference of the Parties, and will ensure that accounting of such targets and finance is rigorous, robust and transparent." 103

The concept of measurement, reporting, and verification (MRV) was first introduced in the Bali Action Plan, signed in December 2007. In paragraphs 1(b)(i) and (ii), addressing mitigation, the Plan called for consideration of:

Measurable, reportable and verifiable nationally appropriate mitigation commitments or actions, including quantified emission limitation and reduction objectives, by all developed country Parties ... ; [and]

Nationally appropriate mitigation actions by developing country Parties in the context of sustainable development, supported and enabled by technology, financing and capacitybuilding, in a measurable, reportable and verifiable manner.... ${ }^{104}$

This idea builds from requirements under the UNFCCC and the Kyoto Protocol. The UNFCCC and the Kyoto Protocol require states to report on their own performance in a form of national reports (communications). ${ }^{105}$ Reporting requirements are different for Annex I (developed) and non-Annex I (developing) countries. Annex I parties are required to report GHG emissions and transactions of emissions units under the Kyoto Protocol flexibility mechanisms in order to assess their compliance with their emission targets. ${ }^{106}$

${ }^{103}$ U.N. Framework Convention on Climate Change [UNFCCC], Fifteenth Conference of the Parties, Copenhagen, Den., Dec. 7-18, 2009, Copenhagen Accord, If 4, U.N. Doc. FCCC/CP/2009/L.7 (Dec. 18, 2009) (draft decision), available at http://unfccc.int/files/meet ings/cop_15/application/pdf/copl_cph_auv.pdf.

${ }^{104}$ U.N. Framework Convention on Climate Change [UNFCCC], Thirteenth Conference of the Parties, Bali, Indon., Dec. 3-15, 2007, Report of the Conference of the Parties, If 1(b)(i)-(iii), U.N. Doc. FCCC/CP/2007/6/Add.1 (Mar. 14, 2008) [hereinafter Bali Action Plan], available at http://unfccc.int/resource/docs/2007/cop13/eng/06a01.pdf.

${ }^{105}$ UNFCCC, National Reports, http://unfccc.int/national_reports/items/1408.php (last visited June 19, 2010).

${ }^{106}$ Id. 
Non-Annex 1 parties report nationally appropriate mitigation actions (NAMAs). ${ }^{107}$

Preparation of national reports may include a participatory process and the input of civil society in verifying the accuracy of national reports. As two scholars explain, this happens more often in the human rights arena:

In the human rights arena, NGOs write extensive analyses of national reports, which are considered by the various human rights supervisory institutions. In the environmental arena, NGOs play a less prominent role, but are very active in investigating national performance in areas such as trade in wildlife and hazardous wastes. ${ }^{108}$

Under the Aarhus Convention, preparation of national reports is a participatory process: NGOs provide comments and in some countries submit alternative reports. ${ }^{109}$ Under the UNFCCC and the Kyoto Protocol, review is performed by a team of experts. ${ }^{110}$ On national level verification can be done by government agencies, non-governmental actors, and independent experts. ${ }^{111}$

The Bali Action Plan anticipated that a new climate agreement would provide for the measurement, reporting, and verification (MRV) of three categories of action: developed country mitigation commitments or actions, developing country mitigation actions, and the provision of support for developing country mitigation actions. ${ }^{12}$ MRV can serve a wide range of purposes in a new climate agreement. ${ }^{113}$ One of the main goals is transparency and access to information about the progress in achieving the Convention objective by individual countries and the international community as a whole.

107 Id.

108 Clare Breidenich \& Daniel Bodansky, Pew Ctr. on Global Climate Change, MEASUREMENT, REPORTING AND VERIFICATION IN A POST-2012 CLIMATE AGREEMENT 10 (2009), available at http://www.pewclimate.org/docUploads/mrv-report.pdf.

${ }^{109}$ U.N. Econ. \& Soc. Council [ECOSOC], Econ. Comm'n for Europe [ECE], Third Meeting of the Parties to the Convention on Access to Information, Public Participation in DecisionMaking and Access to Justice in Environmental Matters, Report of the Compliance Committee, I 19, U.N. Doc. ECE/MP.PP/2008/5 (May, 22, 2008).

${ }^{110}$ See National Reports, supra note 105 (stating that "[e]ach national communication of an Annex I Party is subject to an 'in-depth' review conducted by an international team of experts").

111 Id.

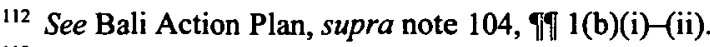

113 See BREIDENICH \& BODANSKY, supra note 108, at 7 (noting that "[a] wide variety of quantitative and qualitative information can, in principle, be verified" by MRV). 


\section{Public Participation in Decision-Making Related to Climate Change}

\section{A. Legal Framework}

Public participation as a right, or at least a principle, in international environmental law was first established in Agenda 21:

One of the fundamental prerequisites for the achievement of sustainable development is broad public participation in decisionmaking. Furthermore, in the more specific context of environment and development, the need for new forms of participation has emerged. This includes the need of individuals, groups and organizations to participate in environmental impact assessment procedures and to know about and participate in decisions, particularly those which potentially affect the communities in which they live and work. ${ }^{114}$

Principle 10 of the Rio Declaration states:

Environmental issues are best handled with participation of all concerned citizens, at the relevant level. At the national level, each individual shall have appropriate access to information concerning the environment that is held by public authorities ... and the opportunity to participate in decision-making processes. States shall facilitate and encourage public awareness and participation by making information widely available. ${ }^{115}$

This principle was included in many global and regional MEAs. ${ }^{116}$ For instance, Article 4(1)(i) of the UNFCCC obliges parties to "encourage the widest participation in this process, including that of non-governmental

\footnotetext{
${ }^{114}$ U.N. Conference on Environment and Development, Rio de Janeiro, Braz., June 3-14, 1992, Agenda 21, 23.2, U.N. Doc. A/CONF/151/26 (vol. III) (Aug. 14, 1992), available at http://www. un.org/esa/dsd/agenda21/res_agenda21_23.shtml.

${ }^{115}$ Rio Declaration, supra note 27.

116 Joint UNEP-OHCHR Expert Seminar on Human Rights and the Environment, Geneva, Switz., Jan. 14-16, 2002, Background Paper No. 1: Human Rights and Environment Issues in Multilateral Treaties Adopted Between 1991 and 2001 (prepared by Dinah Shelton), available at http://www2.ohchr.org/english/issues/environment/environ/bpl.htm.
} 
organizations." 117 Article 6 further provides that parties shall "[p]romote and facilitate at the national and, as appropriate, subregional and regional levels, and in accordance with national laws and regulations, and within their respective capacities," the public's access to information and public participation. ${ }^{18}$

The Espoo Convention on Environmental Impact Assessment in a Transboundary Context guarantees non-discriminatory public participation in environmental impact procedures within the scope of the UNFCCC. ${ }^{119}$ Article 2(6) states that:

The Party of origin shall provide ... an opportunity to the public in the areas likely to be affected to participate in relevant environmental impact assessment procedures regarding proposed activities and shall ensure that the opportunity provided to the public of the affected Party is equivalent to that provided to the public of the Party of origin. ${ }^{120}$

A comprehensive approach to public participation is established by the Aarhus Convention. ${ }^{121}$ According to Article 6 of the Aarhus Convention, public participation is guaranteed and required in regard to all decisions on whether to permit activities which may have a significant impact on the environment. The public shall be informed about the proposed activity "early in the decision-making procedure and in an adequate, timely and effective manner." 122 The public participation procedures shall include reasonable time allowing the public "to prepare and participate effectively during the environmental decision-making." ${ }^{23}$ The public must have access to all relevant information on the proposed activities including, inter alia, a description of environmental impacts, measures to prevent or mitigate the effects, a non-technical summary of documents, and main alternatives. ${ }^{124}$

\footnotetext{
117 UNFCCC, supra note 34, art. 4(1)(i).

${ }_{118} I d$. arts. 6(a), 6(a)(ii)-(iii).

119 Convention on Environmental Impact Assessment in a Transboundary Context, Feb. 25, 1991, 1989 U.N.T.S. 309, available at http://www.unece.org/env/eia/documents/legaltexts/co nventiontextenglish.pdf [hereinafter Espoo Convention].

${ }^{120}$ Id. art. 2(6).

121 See Aarhus Convention, supra note 28, arts. 6-8.

${ }^{122}$ Id. art. $6(2)$.

${ }^{123}$ Id. art. 6(3)

${ }^{124}$ Id. art. 6(6).
} 
Public participation can be in the form of written or oral comments. ${ }^{125}$ The outcomes of public participation shall be taken into account. ${ }^{126}$ All decisions shall be made public, along with the reasons and considerations on which the decision is based. In addition to providing for public participation regarding decisions on specific projects, the Aarhus Convention promotes public participation in the preparation of environmental plans, programs, policies, ${ }^{127}$ and regulations. ${ }^{128}$

The Aarhus Convention is particularly relevant in advancing the concept of public participation in international decision-making. According to Article 3.7, "[e]ach Party shall promote the application of the principles of this Convention in international environmental decision-making processes and within the framework of international organizations in matters relating to the environment." 29 The Working Group of the parties of the Aarhus Convention at its twelfth meeting in Geneva emphasized the application of the Aarhus principles to the UNFCCC and in particular to participation of civil society for the next Conference of the Parties, COP-16, of the UNFCCC..$^{130}$ The Working Group noted that the UNFCCC Secretariat was inviting submissions regarding ways to enhance the engagement of observer organizations in its processes, and stated that "making a submission would provide an immediate opportunity for Parties to the Aarhus Convention to implement their obligations under Article 3, paragraph 7 of the Aarhus Convention." Specifically, the Working Group took note of the suggestion that the parties may wish to consider appointing one or two members of their national delegation for COP-16 (to be held in Cancun, Mexico, November 29-December 10,2010) to act as a focal point for civil society regrading any problems they may encounter in seeking access to information or public participation during the conference itself. ${ }^{131}$ Furthermore, the Working Group took note of the invitation by the Chair of the Task Force on Public Participation in International Forums to implement national focal points to report on initiatives and promote the implementation

${ }^{125}$ Id. art. 6(7).

${ }^{126} \mathrm{Id}$. art. 6(8).

${ }^{127}$ Id. art. 7.

128 Id. art. 8.

${ }^{129}$ Aarhus Convention, supra note 28.

${ }^{130}$ U.N. Econ. \& Soc. Council [ECOSOC], Report on the Fourth Meeting of the Task Force on Public Participation in International Forums, U.N. Doc. UNECE/MP.PP/WG.1/2010/4 (Apr. 28, 2010) [hereinafter Report of the Working Group, Twelfth Meeting].

131 Id. at 5 . 
of paragraph 7 of Article 3, and the Almaty Guidelines ${ }^{132}$ in the lead-up to, during, and after COP-16. ${ }^{133}$

\section{B. Public Participation in EIA}

The UNFCCC requires public participation in addressing climate change and its effects and in developing adequate responses. ${ }^{134}$ This provision of the UNFCCC can be used in various ways, including demanding participation in the environmental assessment of certain projects and activities that emit GHGs contributing to climate change. Case law involving environmental impact assessment and climate change is evolving in various national courts.

A recent research study "revealed that [the Thai] government has continuously promoted heavy and petrochemical industries in Maptapud [Thailand] at the expense of the environment, coastal resources and the health of its residents. ${ }^{135}$ Promotion of these industries runs contrary to Article 67 of Thailand's 2007 Constitution, which guarantees the "right of a person to participate with State and communities in the preservation and exploitation of natural resources" and "in the protection, promotion and conservation of the quality of the environment." 136 It also states:

Any project or activity which may seriously affect [communities with respect to] the quality of the environment, natural resources and biological diversity shall not be permitted, unless its impacts on the quality of the environment and on health of the people in the communities have been studied and evaluated and consultation with the public and interested parties have been organised, and opinions of an independent organisation,

${ }^{132}$ U.N. Econ. \& Soc. Council [ECOSOC], Meeting of the Parties to the Convention on Access to Information, Public Participation in Decision-making and Access to Justice in Environmental Matters, Almaty, Kaz. May 25-27, 2005, Decision II/4: Promoting the Application of the Principles of the Aarhus Convention in International Forums, U.N. Doc. ECE/MP.PP/2005/2/Add.5 (June 20,2005). This document is more commonly referred to as the Almaty Guidelines.

${ }^{133}$ Report of the Working Group, Twelfth Meeting, supra note 130.

134 See UNFCCC, supra note 34, arts. 4, 6 (addressing the need for public participation in climate change discussions).

${ }^{135}$ Maptapud, Thailand Top Priority in Environmental Clean-Up, http://www.accessinitia tive.org/blog/2010/01/maptapud-thailand-top-priority-environmental-clean (Jan. 13, 2010).

${ }^{136}$ CONSTITUTION OF THE KıNGDOM OF THAILAND § 67, B.E. 2550 (2007), available at http:// www.asianlii.org/th/legis/const/2007/1.html. 
consisting of representatives from private environmental and health organisations and from higher education institutions providing studies in the field of environment, natural resources or health, have been obtained prior to the operation of such project or activity. ${ }^{137}$

Twenty-seven Maptapud residents successfully used the right of public participation in the preparation of environmental impact assessments (EIAs), as required by the Constitution of Thailand, by filing a lawsuit against the National Environment Board to stop the construction of sixty-five industrial projects in Maptapud, the largest industrial estate in Thailand, and the world's eighth-largest petrochemicals hub. ${ }^{138}$ Since these sixty-five projects failed to conduct an EIA before starting construction, the Supreme Administrative Court in December 2009 declared these projects unconstitutional and granted an injunction to halt sixty-five projects in the Maptapud industrial estate. ${ }^{139}$ This case has become a landmark in Thailand's environmental movement, leading to a cascade of decisions that halted about $\$ 9$ billion worth of industrial projects. ${ }^{140}$ The case also demonstrates how the right to public participation can stop a project that contributes to climate change.

Another landmark decision was made in the November 2006 case Gray v. Minister for Planning in New South Wales (NSW) by the Land and

${ }^{137}$ Id.

138 The Maptapud estate comprises 117 industrial plants including forty-five petrochemical factories, eight coal-fired power plants, and twelve chemical fertilizer factories. Maptapud, Thailand Top Priority in Environmental Clean-Up, supra note 135. According to the U.S. Environmental Protection Agency, the largest source of $\mathrm{CO} 2$ emissions globally is the combustion of fossil fuels such as coal, oil and gas in power plants, automobiles, industrial facilities and other sources. A number of specialized industrial production processes and product uses such as mineral production, metal production and the use of petroleum-based products can also lead to $\mathrm{CO} 2$ emissions.

U.S. EPA, Climate Change - Greenhouse Gas Emissions, Human-Related Sources and Sinks of Carbon Dioxide, http:/www.epa.gov/climatechange/emissions/co2_human.html (last visited June 20, 2010).

${ }^{139}$ Daniel Ten Kate \& Suttinee Yuvejwattana, Thai Court Upholds Suspension of Industrial Projects (Update 1), BLOOMBERG, Dec. 2, 2009, http://www.bloomberg.com/apps/news?pid=2 0601080\&sid=aWJ_8.nUwzVM.

140 Thomas Fuller, In Industrial Thailand, Health and Business Concerns Collide, N.Y. TIMES, Dec. 19, 2009, at A5, available at http://www.nytimes.com/2009/12/19/world/asia/19 thai.html?_r=2\&sq=thailandpoppulationcase\&st=cse\&scp=1\&pagewanted=all. 
Environment Court. ${ }^{141}$ The court ruled that an EIA for a large coal mine known as the Anvil Hill Project must address global warming. Judge Nicola Pain decided:

[T] here is a sufficiently proximate link between the mining of a very substantial reserve of thermal coal in NSW, the only purpose of which is for use as fuel in power stations, and the emission of GHG which contribute to climate change/global warming, which is impacting now and likely to continue to do so on the Australian and consequently NSW environment, to require assessment of that GHG contribution of the coal when burnt in an environmental assessment under Pt 3A. ${ }^{142}$

One of the main arguments of the plaintiff was that members of the public must be "properly informed in order to determine if they wish to make submissions."143 Soon thereafter, the Land and Resources Tribunal of Queensland took the opposite position in Re Xstrata Coal Queensland Pty Ltd. $\&$ Ors, ruling that that an EIA for a coal mine need not assess greenhouse gas emissions. ${ }^{144}$ This issue, therefore, is regarded as unsettled in Australia.

In the United States, Friends of the Earth, Greenpeace, and four cities sued the Export-Import Bank (Ex-Im) and the Overseas Private Investment Corporation (OPIC) ${ }^{145}$ Plaintiffs alleged that the defendants failed to evaluate the effects of their "financial support ... [of] fossil fuel projects that emit greenhouse gases" on global climate change. ${ }^{146}$ The parties argued that the defendants were "required to conduct an environmental review under NEPA [National Environmental Policy Act]." 147 The court ruled that Ex-Im and OPIC are not completely exempt from NEPA requirements. ${ }^{148}$ The court did not, however, make a decision as to whether Ex-Im or OPIC had enough authority

${ }^{141}$ Gray v. Minister for Planning \& Ors (2006), 156 Loc. Gov't \& Envtl. Rep. Austl. 258, available at http://www.lawlink.nsw.gov.au/lecjudgments/2006nswlec.nsf/61 f584670edbfba2c a2570d40081 f438/dc4df619de3b3f02ca257228001 de798? OpenDocument.

${ }^{142}$ Id. || 100.

${ }^{143}$ Id. $\| 28$.

144 Re Xstrata Coal Queensland Pty Ltd., (2007) Q. Land \& Res. Ct. ๆा 22-24, 33 (Austl.), available at http://www.austlii.edu.au/au/cases/qld/QLRT/2007/33.html.

${ }_{145}$ Friends of the Earth, Inc. v. Mosbacher, 488 F. Supp. 2d 889, 891 \& n.1 (N.D. Cal. 2007).

${ }^{146} \mathrm{Id}$. at 892.

${ }_{147}$ Id.

${ }^{148}$ Id. at 908. 
over the specific projects in issue that funding must be subject to EIA requirements. ${ }^{149}$

\section{Public Participation in Transboundary EIA}

Climate change also raises the issue of the potential impacts of a project in one country on climate change across transboundary borders and even globally. For example, the reconstruction of the biggest coal-burning power plant in the Czech Republic, Prunerov II, may have significant transboundary environmental impacts on the Federal Republic of Micronesia (FRM). "The Czech Environment Ministry will delay a ruling on the reconstruction of Prunerov, the country's biggest coal-burning power plant and largest producer of greenhouse gases, ${ }^{150}$ until a foreign team of experts can evaluate the project's environmental impact assessment ...." ${ }^{151}$ The Environment Ministry had been expected to rule on the environmental impact assessment on January 4,2010 . However, a petition by Micronesia ${ }^{152}$ to be included in the transboundary EIA regarding the complex renovation of the Prunerov II power plant resulted in a delay of the Ministry's decision. The Pacific nation's approach represented a precedent-setting way for vulnerable countries to challenge projects that contribute to climate change. ${ }^{153}$ The Federated States

${ }^{149}$ Id. at $918-19$.

150 See Letter from Andrew Yatilmon on behalf of the Federated States of Micronesia to Ing. Karel Blaha, Deputy Minister, Ministry of the Environment of the Czech Republic (Jan. 4, 2010), available at http://www.pohodacez.cz/files/file/Viewpoint $\% 20$ of $\% 20 F S M \% 20$ on $\% 20$ renovation $\% 200 \mathrm{of} \% 20 \mathrm{Prunerov} \% 2011 \% 20 \mathrm{Plant}$.pdf [hereinafter Viewpoint of FRM] ("The Prunerov II power plant is 18 th biggest source of greenhouse gases in the European Union. This single plant emits 40 times more $\mathrm{CO} 2$ than the entire Federation of States of Micronesia .... [There are] another 209 (two hundred and nine) countries around the world whose annual $\mathrm{CO} 2$ emissions are lower than those of Prunerov.").

${ }^{151}$ Eva Munk, Czech Officials Ask Foreign Team to Review Coal Plant Reconstruction Protested by Micronesia, WORLD ClimATE CHANGE REP., Jan. 1, 2010, available at http://www. climate.bna.com (subscription required). Prunerov is owned by Ceske Energeticke Zavody (CEZ), the country's state-controlled energy monopoly. The CEZ says that a $\$ 1.3$ billion reconstruction "will raise the efficiency of the plant from 32 percent to 39 percent and lower carbon dioxide and other greenhouse gas emissions by 30 percent and 50 percent, respectively." Id. Environmental activists and FRM, however, argue that CEZ is not using the best available technology (BAT), which could bring the plant's effectiveness up to $42 \%$. CEZ says the environmentalists' proposition is not technically or economically feasible. Id.

${ }^{152}$ See Viewpoint of FRM, supra note 150 (providing input on the environmental impact of Prunerov).

${ }^{153}$ Munk, supra note 151. 
of Micronesia (FSM) alleges that the EIA failed to assess all potential impacts and all possible alternatives to minimize the adverse impacts of the modernization of the power plant. ${ }^{154}$ FSM argues that using outdated technology (below the BAT threshold) in planned modernization during the next twenty-five years will result in an additional nine million tons of emitted $\mathrm{CO} 2 .^{155}$

The national government identified four climate change phenomena which represent a significant threat to the well-being of the environment, among them, accelerated sea-level rise, El Niño effects, La Nina effects, and GHG emissions. ${ }^{156}$ Although FRM is

aware that GHG emissions produced solely by Prunerov II will not directly cause sea-level rise ... and increased storms, there are approximately only 5000 such power plants which contribute to total global $\mathrm{CO} 2$ emissions. Therefore every single power plant clearly plays an important role and warrants a transboundary impact assessment. ${ }^{157}$

Whether the foreign team of experts will give the citizens of the Czech Republic and FSM the possibility to participate in transboundary EIA procedures remains to be seen. This procedure is itself unprecedented and has to be developed. The only international treaty regarding transboundary impact assessment is the Espoo Convention. ${ }^{158}$ The Espoo Convention requires parties to notify and consult each other on all major projects under consideration that might have adverse environmental impacts across borders bringing together all stakeholders to prevent environmental damage before it occurs. ${ }^{159}$ It has strong public participation provisions for both the "Party of origin" and the "affected Party" and could be used to combat climate change in Europe. ${ }^{160}$ The problem in this case is that FSM is not a party to the Espoo Convention. FSM may, however, use the Settlement of Dispute procedure under Article 14 of the

\footnotetext{
${ }^{154}$ Viewpoint of FRM, supra note 150.

${ }^{155}$ Id.

${ }^{156} \mathrm{Id}$.

${ }^{157}$ Id.

${ }^{158}$ Espoo Convention, supra note 119.

${ }^{159}$ Id. art. 3.

${ }^{160}$ Id.
} 
UNFCCC, including a submission to the International Court of Justice, if its petition is not resolved under Czech and European Union law. ${ }^{161}$

\section{The Role of Civil Society in Climate Change Negotiations: COP-15}

Since the World Summit in Rio de Janeiro and the Rio Declaration's Principle 10 statement that "environmental issues are best handled with the participation of all concerned citizens," the public has regularly participated in negotiations of international treaties, including the UNFCCC and the Kyoto Protocol. ${ }^{162}$ The public is allowed to observe the Conferences of the Parties (COPs). During COP-15, 14,000 representatives of civil society and NGOs were registered including Greenpeace International, Oxfam International, Climate Action Network (CAN) International, Ecosystems Climate Alliance (ECA), World Wildlife Fund (WWF), Earthjustice, Friends of the Earth, and others. Many observer organizations brought valuable expertise to the negotiation; some of them participated in climate change negotiations for many years developing expertise, knowledge, and negotiation skills. During COP-15, NGOs played a crucial role crafting draft text and analysis, providing their scientific, legal and other expertise, and lobbying governments. This role was particularly vital for parties with small delegations that lacked experts, lawyers, scientists, and diplomats which many wealthy parties deployed. In addition, civil society played an important role in raising public awareness about the negotiation and position of certain governments, building public and political support.

During last two days of the COP-15 observers and civil society constituencies were excluded from negotiation. ${ }^{163}$ Restricted access to negotiations resulted in disappointment among civil society and resulted in a letter of "Outrage at Exclusion of Civil Society from the Climate Change Negotiations in Copenhagen" addressed to the UN Secretary-General Ban Ki Moon, Executive Secretary of the UNFCCC Secretariat Yvo de Boer, and

161 UNFCCC, supra note 34, art. 14.

${ }^{162}$ Rio Declaration, supra note 27, princ. 10.

163 Tobin Hack, Lockout: Civil Society Groups Denied Access to COP15, BIG THINK, http:// bigthink.com/ideas/17943 (last visited June 20,2010). "According to a memo sent out by the observer organization liaison, the 22,000 registered observers were limited to 7000 today [December 9], on Thursday [December 10] this numbers [sic] will be further limited to 1000 , and on Friday [December 11] only 90 observers will be permitted access to the negotiations." Civil Society Constrained at COP 15 , http://itsgettinghotinhere.org/2009/12/15/civil-society-cons trained-at-cop15/ (last visited June 20, 2010). 
Prime Minister of Denmark Lars Lokke Rasmussen. ${ }^{164}$ This exclusion and treatment by the UNFCCC Secretariat and Danish Government, in the opinion of the authors of the letter, were "utterly unacceptable" and "reflect[ed] badly on the UNFCCC and Government of Denmark" and "the United Nations as a whole." 165 Restriction of access to COP-15 undercut the role of civil society, legitimacy and democratic process of negotiations. It violated Article 6 of the UNFCCC and Rule 7 of the Rules of Procedure. ${ }^{166}$ It also failed to comply with the principles of access to information and public participation embodied in the Aarhus Convention, signed by forty-four countries in Europe, as well as parties to the UNFCCC, including Denmark. ${ }^{167}$

\section{Procedural Rights LANGUAGe IN THE LCA NEGotiation TEXT AND IN THE POST-COPENHAGEN TREATY}

As a member of the Human Rights and Climate Change Working Group (WGHR) ${ }^{168}$ the author was involved in preparing draft proposals for a negotiation text prepared by the Ad Hoc Working Group on Long-term Commitment Action (AWGLCA). The WGHR suggestions are aimed at strengthening human rights language or inserting additional language in order to "respect, protect and promote human rights in the [negotiation] text."169 To protect individuals, communities and peoples most vulnerable to climate change, it must be ensured that human rights are integrated in the final agreement:

${ }^{164}$ Letter prepared by Ecosystems Climate Alliance to U.N. Sec'y Gen. Ban Ki Moon, Executive Sec'y of the UNFCCC Secretariat Yvro de Boen, and Prime Minister of Den. Lars Lokke Rasmussen (on file with author).

${ }^{165}$ Id.

${ }^{166}$ UNFCCC, supra note 34.

${ }^{167}$ See Aarhus Convention, supra note 28.

${ }^{168}$ Human Rights Climate Change Working Group, Proposed Revisions to Maintain and Strengthen Human Rights Protections in the LCA Text (Dec. 21, 2009), available at http:// www.elaw.org/system/files/HR+in+LCA+Text+\%28HRWG+Proposals\%29+09-12-11-2.pdf ("Representatives of the following organizations are members of the HUMAN RIGHTS \& CLIMATE CHANGE WORKING GROUP and support the effort to include human rights protections in the final treaty text: Australian Climate Justice Program, Center for International Environmental Law, Climate Law \& Policy Project, Earthjustice, Friends of the Earth, Many Strong Voices and WWF.").

${ }^{169}$ Id. 
Existing language in the shared vision explicitly recognizes that climate impacts have implications for the full and effective enjoyment of human rights. This language should be strengthened by referring to the link between the environment and human rights recognized in the Stockholm Declaration, itself referred to in the UNFCCC. The shared vision should also emphasize that a successful international climate framework must include effective mechanisms for participation at the local, national and international levels, thus reinforcing Article 6 of the UNFCCC and the Rio Declaration. ${ }^{170}$

The WGHR suggested amending paragraph 8 of non-paper 33 to strengthen participatory rights in the LCA text by the following language: "All stakeholders be they governmental, including subnational and local government, private business or civil society, including the youth, and addressing the need for gender equity should have access to information, full, early and effective participation, and access to justice with respect to climate change adaptation and mitigation actions." 171 The group proposed to replace paragraph 4(f) of non-paper 31 to strengthen participatory rights in the LCA text by the following language on the implementation of enhanced action on adaptation - the implementation of the adaptation shall: "(f) [b]e planned, implemented, supported, monitored and reported on in a manner that guarantees the rights of all relevant stakeholders to access to information, full, early and effective participation, and access to justice." ${ }^{172}$ A similar proposal was made to strengthen the participatory rights in mitigation by including in paragraph 4(e) of non-paper 39 the following:

[R]ights to land, territories and all resources and free, prior and informed consent, and members of local communities; ensure access to information, access to justice and full, early, and effective participation of all relevant stakeholders, including indigenous peoples, forest dwellers and local communities, prior to and during the design, planning, implementation, monitoring

170 Id. Non-papers represent the work undertaken by the contact groups and sub-groups established by the Ad Hoc Working Group on Long-term Cooperative Action under the UNFCCC.

${ }^{171} I d$. at Proposal 4.

172 Id. at Proposal 7. 
and evaluation of actions ... and ensure that indigenous peoples have the right to participate through representatives chosen by themselves in accordance with their own procedures and decision-making institutions .... ${ }^{173}$

The group also suggested creating a mechanism to receive communications from members of the public to ensure that implementation of the Convention is consistent "to protect and promote the full enjoyment of indigenous peoples' collective human rights." 174

This kind of compliance mechanism was inspired by a similar mechanism under the Aarhus Convention that accepts communications from the public. ${ }^{175}$ The successful efforts to allow the public to bring non-compliance to the attention of the Aarhus Convention Compliance Committee have been replicated in the Protocol on Water and Health to the Convention on the Protection and Use of the Transboundary Watercourses and International Lakes. ${ }^{176}$ Other MEAs, including the UNFCCC and the Kyoto Protocol, do not allow communications of the public. In most MEAs, the triggers of the compliance procedure can be submissions by one party against another party, by the Secretariat, or by a party in respect to itself(self-reporting), but only the third is common. Party-to-party submissions are rare and unusual. ${ }^{177}$ Communications from the public, if allowed by the Kyoto Protocol Compliance Committee or in other related treaties, can be a valuable channel of information about parties' non-compliance.

${ }^{173}$ Id. at Proposal 13.

174 Id. at Proposal 5.

175 See Svitlana Kravchenko, The Aarhus Convention and Innovations in Compliance with Multilateral Environmental Agreements, 18 CoLO. J. INT'LENVTL. L. \& POL'Y 1, 10-23 (2007) (discussing NGO nomination to the Compliance Committee and communications from the public as triggers of the compliance procedure).

${ }^{176}$ U.N. Econ. \& Soc. Council [ECOSOC], Econ. Comm'n for Europe [ECE], Meeting of the Parties to the Convention on the Protection and Use of Transboundary Watercourses and International Lakes, Protocol on Water and Health to the 1992 Convention on the Protection and Use of Transboundary Watercourses and International Lakes, U.N. Doc. MP.WAT/2000/1 (Oct. 18, 1999), available at $\mathrm{http} / / \mathrm{www}$.unece.org/env/documents $/ 2000 / \mathrm{wat} / \mathrm{mp} . \mathrm{wat} .2000 .1$.e.pdf.

${ }^{177}$ This statement is based on the author's search of the websites of several MEAs (such as the Espoo (EIA) Convention, Geneva Convention on Long-Range Transboundary Air Pollution, Montreal Protocol, Basel Convention, and Aarhus Convention), and of academic literature, for example, Markus Ehrmann, Procedures of Compliance Control in International Environmental Treaties, 13 COLO. J. INT'L. ENVTL. L. \& POL'Y 377, 390-415 (2002) (discussing the Montreal Protocol's negotiating history, procedural steps, functioning of the non-compliance procedure, and the author's conclusions). 
In the final formal report of the AWGLCA to the COP-15, core language on human rights was included into two paragraphs of the preamble:

Noting resolution 10/4 of the United Nations Human Rights Council on human rights and climate change, which recognizes that human beings are at the centre of concerns for sustainable development, and the importance of respecting Mother Earth, its ecosystems and all its natural beings,

Mindful that the adverse effects of climate change have a range of direct and indirect implications for the full enjoyment of human rights, including living well, and that the effects of climate change will be felt most acutely by those parts of the population that are already vulnerable owing to youth, gender, age or disability .... ${ }^{178}$

The outcome of the work undertaken by the drafting groups during the last few days of COP-15 was of an informal nature and the texts contained in this document, therefore, have no formal standing. Following the closure of the AWGLCA session, the COP-15 extended the mandate of the AWGLCA. The AWGLCA "continues its work, with a view to presenting the results of its work to the COP for adoption at its sixteenth session."179 This document probably will form the basis of the next version of the negotiating text. Although core human rights language was included in AWGLCA text, it needs to be improved before and during the next COP, especially in terms of procedural rights. Therefore, the Human Right and Climate Change Working Group continues its work and results remain to be seen.

${ }^{178}$ UNFCCC, Ad-Hoc Working Group on Long-Term Cooperative Action Under the Convention (AWG-LCA), Report of the AWG-LCA on its Eighth Session Held in Copenhagen, Annex I, pmbl., U.N. Doc. FCCC/AWGLCA/2009/17 (Feb. 5, 2010), available at http://unfccc. int/resource/docs/2009/awglca8/eng/17.pdf.

${ }^{179}$ Conference of the Parties to the UNFCCC, Work Undertaken by the Conference of the Parties at its Fifteenth Session on the Basis of the Report of the AWG-LCA, U.N. Doc. FCCC/CP/2010/2 (Feb. 11, 2010), available at http://unfccc.int/resource/docs/2010/cop16/eng/ 02.pdf. 


\section{CONCLUSION}

The human rights approach to climate change is becoming increasingly recognized in the human rights field. The UN Human Rights Council adopted Resolution 10/4 on "human rights and climate change" in which it recognized that "climate change-related impacts have a range of implications for the effective enjoyment of human rights." ${ }^{\text {" }}$ A human rights approach has several advantages - strong language of human rights treaties, established institutions, and developed case law. A human rights approach helps to find solutions to problems for which environmental law does not have a response. Human rights have moral values which help to put a human face on the abstract climate change problem. It helps to draw political attention to climate change and to raise public awareness.

Procedural rights are a crucial tool to combat climate change. Access to information on emission trading, climate change projects, and policies can help to avoid double accounting, leakage, and fraud. Public participation and civil society input in preparation of national reports under the UNFCCC will verify their accuracy. Participation of civil society in measurement, reporting, and verification (MRV) will ensure their transparency. Access to information about the progress in achieving the UNFCCC's objective by individual countries and the international community as a whole will strengthen the prospects for success. Participation of a full range of stakeholders-including state representatives, international human rights bodies, indigenous peoples, and civil society - in international negotiations would make certain that all mitigation and adaptation policies incorporate international human rights standards and include the voices of the most vulnerable groups affected by climate change.

Using a procedural rights approach does not mean that we need to give up environmental law tools. Procedural rights can make valuable contributions in expanding the diversity of policies and tools in the climate change regime.

180 See Office of the United Nations High Commissioner for Human Rights, Human Rights and Climate Change, http://www2.ohchr.org/english/issues/climatechange/index.htm(last visited July 25, 2010) (linking to Resolution 10/4). 